\title{
Mites (Acari, Mesostigmata) from rock cracks and crevices in rock labirynths in the Stolowe Mountains National Park (SW Poland)
}

\author{
JACEK KAMCZYC and MACIEJ SKORUPSKI \\ Department of Game Management and Forest Protection, Poznan University of Life Sciences, \\ Wojska Polskiego 71C, 60-625 Poznań
}

Corresponding author: Jacek Kamczyc, jkam@up.poznan.pl

(Received on 7 January 2013; Accepted on 7 April 2014)

\begin{abstract}
The aim of this study was to recognize the species composition of soil mites of the order Mesostigmata in the soil/litter collected from rock cracks and crevices in Szczeliniec Wielki and Błędne Skały rock labirynths in the area of the Stołowe Mountains National Park (part of the Sudetes in SW Poland). Overall, 27 species were identified from 41 samples collected between September 2001 and August 2002. The most numerous species in this study were Veigaia nemorensis, Leptogamasus cristulifer, and Gamasellus montanus. Our study has also confirmed the occurrence or rare mite species, such as Veigaia mollis and Paragamasus insertus. Additionally, 5 mite species were recorded as new to the fauna of this Park: Vulgarogamasus remberti, Macrocheles tardus, Pachylaelaps vexillifer, Iphidosoma physogastris, and Dendrolaelaps (Punctodendrolaelaps) eichhorni.
\end{abstract}

Keywords: mesofauna, mites, Mesostigmata, soil, rock cracks, crevices

\section{INTRODUCTION}

The Stołowe Mountains National Park (also known as the Góry Stołowe NP) was established in 1993, in the area of the only table hills in Poland, mainly due to the occurrence of the very specific sandstone landscapes, including rocks labyrinths. The rock labyrinths are generally composed of sandstones blocks, separated by cracks and crevices (SzOPKA 2002). The rock cracks are characterized by mountain microclimate with higher relative humidity (90-98\%) and low temperature (c.a. +8 to $+12^{\circ} \mathrm{C}$ in summer), which differ from the surroundings (BALDY \& WoźNY 1998; SMOLIS \& POMORSKI 1998).

Previous studies of spiders and collembolans suggest that the rock labyrinths are inhabited by arctic, alpine or cave species (BALDY 2002; RYBAK \& BALDY 2003, SMOLIS 2003). Spiders are represented there e.g. by the glacial relict Bathypantes eumenis (L. Koch), the alpine Leptyphantes pulcher (Kulczyński), which occurs above 2000 
a.s.1., and the cave species Meta menardi (Latreille, 1804). The spider communities, however, are dominated by the hygrophilous species Centromerus arcanus (O.P.Cambridge, 1873) (WoźNY \& CZAJKA 1985; BALDY \& WoźNY 1998). Similarly, SMOLIS and POMORSKi (1998) have recorded the cave species of collembolan Schaefferia emucronata Absolon, 1990, which occurs in Europe in the Alps and Pyrenees. They also found the boreal-mountain species Folsomia sensibilis Kseneman, 1936 and the hygrophilous Proisotoma recta Stach, 1930, which occurs in the Tatra Mountains. Gwiazdowicz and Kamczyc (2009) described from the Szczeliniec Wielki plateau one Arctoseius species new to science. Many species from this mesostigmatid genus are abundant in the polar deserts and arctic tundra (LINDQUIST \& MAKAROVA 2011).

So far, published studies in the Stołowe Mountains National Park have led to the discovery of 94 mesostigmatid species. Those studies were focused on investigation of a selected mite family (MicherdZińSKi 1969; KACZMAREK \& MARQUARDT 2006), genus (BŁoszyK 1980), species (BŁoszyK \& Olszanowski 1984; Kamczyc 2006a, b; GwIAZDOWICZ \& KAMCZYC 2009) or were faunistic investigations in various microhabitats (SKORUPSKi \& GoŁoJUCH 1996a, b; SKORUPSKi et al. 1998) or only in soil (KAMCZyC \& GwiazDOwicz 2009). However, there is no published information about mesostigmatids in very specific microhabitats. That is why the main aim of this study was to investigate the mesostigmatid mite community in the litter and soil in rock cracks and crevices in the Szczeliniec Wielki and Błędne Skały rock labyrinths, to determine if its species composition is unique.

\section{MATERIALS AND METHODS}

The investigations were carried out in Szczeliniec Wielki and Błędne Skały rock labyrinths in the Stołowe Mountains NP (part of the Sudetes in south-western Poland). The Szczeliniec Wielki labyrinth $\left(50^{\circ} 29^{\prime} \mathrm{N}, 16^{\circ} 20^{\prime} \mathrm{E}\right)$ is a plateau located about $2 \mathrm{~km}$ south-east of Pasterka village, at $919 \mathrm{~m}$ a.s.l., while the Błędne Skały labyrinth $\left(50^{\circ} 28^{\prime} \mathrm{N}, 16^{\circ} 17^{\prime} \mathrm{E}\right)$ is a lower plateau, located north-east of Bukowina Kłodzka village, at $853 \mathrm{~m}$ a.s.l. Both study sites are characterized by deep cracks and crevices in the rock labirynths, and are bordered by steep rock walls ending in wide boulder fields sloaping towards the platforms of the closest villages (Karłów and Bukowina Kłodzka). The forests are early successional stages of the association Leucobryo-Pinetum, very specific and characteristic of the Stołowe Mountains. Scots pine Pinus sylvestris, silver birch Betula pendula and Norway spruce Picea abies dominate in the tree layer in the plateau. The herb layer is dominated by Vaccinium vitis-idaea, V. myrtillus, Dicranum scoparium, and Calluna vulgaris (Plan ochrony eKosysTEMÓW LEŚNYCH 1998).

To conform to the requirements of the obtained sampling permission, which aimed to minimize damage to the sensitive habitats of rock cracks, only 41 soil/litter samples were taken between September 2001 and August 2002, using steel cylinders (depth $0-10 \mathrm{~cm}, 40 \mathrm{~cm}^{2}$ ). Mites were extracted by using Berlese funnels with a mesh size of about $2 \mathrm{~mm}$. The soil/litter cores were heated from above with $40-\mathrm{W}$ bulbs and the extraction lasted 7 days. The organisms were collected in $70 \%$ ethanol, mounted in permanent and semipermanent slides and counted. 
The analysis of the mesostigmatid mite community was based on indexes of dominance $(D$, i.e. $\%$ of the total abundance) and frequency $(F$, i.e. $\%$ of all samples). Dominance classes were defined as follows: eudominants $(>30 \%)$, dominants (15.01-30\%), subdominants $(7.01-15.0 \%)$, recedents $(3.01-7 \%)$, and subrecedents $(<3 \%)$. For frequency, the following classes were used: euconstants $(>50 \%)$, constants $(30.01-50 \%)$, subconstants $(15.01-30 \%)$, accessory species $(5.01-15 \%)$, and accidentals $(<5 \%)$. The rank-abundance curve was used to visualize the proportional abundance of all recorded species in the mite community. The species accumulation curve shows the increase in the number of taxa with increasing sampling effort. Full names of the species and the authors' names are presented in Table 1.

Table 1. Checklist of mesostigmatid mites in the soil/litter collected from the rock cracks and crevices in the Szczeliniec Wielki and Błędne Skały labyrinths in the Stołowe Mountains National Park. Species new to the fauna of this national park are marked in bold

\begin{tabular}{|c|c|c|c|c|c|}
\hline No. & Species & $\begin{array}{l}\text { Adundance } \\
\text { (ind.) }\end{array}$ & $\begin{array}{c}\text { Dominance } \\
(\%)\end{array}$ & $\begin{array}{c}\text { Number of } \\
\text { samples }\end{array}$ & $\begin{array}{c}\text { Frequency } \\
(\%)\end{array}$ \\
\hline 1 & Dendrolaelaps eichhorni Wiśniewski, 1980 & 1 & 0.4 & 1 & 2.4 \\
\hline 2 & Gamasellus montanus (Willmann, 1936) & 35 & 13.9 & 13 & 31.0 \\
\hline 2 & Geholaspis longispinosus (Kramer 1876) & 14 & 5.6 & 4 & 9.5 \\
\hline 4 & Geholaspis pauperior (Berlese 1918) & 8 & 3.2 & 1 & 2.4 \\
\hline 5 & Hypoaspis oblongus (Halbert, 1915) & 3 & 1.2 & 2 & 4.8 \\
\hline 6 & Iphidosoma physogastris Karg, 1971 & 3 & 1.2 & 3 & 7.1 \\
\hline 7 & Leptogamasus cristulifer (Athias, 1967) & 40 & 15.9 & 16 & 38.1 \\
\hline 8 & Leptogamasus obesus (Holzmann, 1969) & 5 & 2.0 & 5 & 11.9 \\
\hline 9 & Macrocheles sp. & 1 & 0.4 & 1 & 2.4 \\
\hline 10 & Macrocheles tardus (C.L. Koch 1844) & 6 & 2.4 & 2 & 4.8 \\
\hline 11 & Pachylaelaps furcifer Oudemans 1903 & 2 & 0.8 & 2 & 4.8 \\
\hline 12 & Pachylaelaps vexillifer Willmann, 1956 & 4 & 1.6 & 3 & 7.1 \\
\hline 13 & Paragamasus insertus (Micherdziński, 1969) & 16 & 6.4 & 12 & 28.6 \\
\hline 14 & Paragamasus neoruncatellus (Schweizer, 1961) & 16 & 6.4 & 11 & 26.2 \\
\hline 15 & Paragamasus vagabundus (Karg, 1968) & 1 & 0.4 & 1 & 2.4 \\
\hline 16 & Pergamasus barbarus (Berlese, 1905) & 2 & 0.8 & 1 & 2.4 \\
\hline 17 & Pergamasus holzmannae Micherdziński 1969 & 1 & 0.4 & 1 & 2.4 \\
\hline 18 & Pergamasus mediocris Berlese, 1904 & 5 & 2.0 & 3 & 7.1 \\
\hline 19 & Porrhostaspis lunulata Muller, 1859 & 4 & 1.6 & 3 & 7.1 \\
\hline 20 & Trachytes aegrota (C.L.Koch, 1841) & 1 & 0.4 & 1 & 2.4 \\
\hline 21 & Uroseius sp. & 1 & 0.4 & 1 & 2.4 \\
\hline 22 & Veigaia cervus (Kramer, 1876) & 2 & 0.8 & 2 & 4.8 \\
\hline 23 & Veigaia kochi (Tragardh, 1901) & 11 & 4.4 & 6 & 14.3 \\
\hline 24 & Veigaia mollis Karg, 1971 & 4 & 1.6 & 2 & 4.8 \\
\hline 25 & Veigaia nemorensis (C. L. Koch, 1839) & 47 & 18.7 & 11 & 26.2 \\
\hline 26 & Vulgarogamasus kraepelini (Berlese, 1905) & 17 & 6.8 & 4 & 9.5 \\
\hline \multirow[t]{2}{*}{27} & Vulgarogamasus remberti (Oudemans, 1912) & 1 & 0.4 & 1 & 2.4 \\
\hline & Total & 251 & 100.0 & - & - \\
\hline
\end{tabular}




\section{RESULTS}

In total, 251 mites (including juveniles and adults) of 27 species were identified. The dominance index $(D)$ was calculated for all the recorded specimens. Overall, the most numerous species were Veigaia nemorensis (47 ind.; $D=18.7$ ), Leptogamasus cristulifer $(40 ; 15.9)$ and Gamasellus montanus $(35 ; 13.9)$, which were classified as eudominants (Fig. 1). Dominants were represented by Vulgarogamasus kraepelini (17; 6.8), Paragamasus insertus $(16 ; 6.4)$, P. neoruncatellus $(16 ; 6.4)$, and Geholaspis longispinosus $(14 ; 5.6)$. The proportional abundance of the other species recorded in this study did not exceed $5.0 \%$ (Table 1 ). No species were classified as euconstants, while constants were represented by Leptogamasus cristulifer $(F=38.1)$ and Gamasellus montanus $(F=31.0)$. Paragamasus insertus $(F=28.6)$ and $P$. neoruncatellus $(F=26.2)$ as well as Veigaia nemorensis $(F=26.2)$ were subconstants. All the other species occurred in less than $15 \%$ of all samples.

The rank-abundance curve rapidly declines from the third species rank; it confirms that the mite community is generally dominated by 3 species (Veigaia nemorensis, Leptogamasus cristulifer and Gamasellus montanus) and many recorded species were much less abundant (Fig. 1). The analysis of the cummulative number of species shows that knowledge of the mesostigmatid mite community, which reached identified 27 species, can increase with the sampling effort. As a result of this study, 5 species were found to be new to the fauna of the Stołowe Mountains National Park: Vulgarogamasus remberti, Macrocheles tardus, Pachylaelaps vexillifer, Iphidosoma physogastris, and Dendrolaelaps (Punctodendrolaelaps) eichhorni.

\section{DISCUSSION}

We expected that the analysed specific microhabitats of rock cracks and crevices are inhabited mostly by rare mesostigmatid species. Surprisingly, we have recorded the dominance of 2 eurytopic mite species, Gamasellus montanus and Veigaia nemorensis, and a single rare species, Leptogamasus cristulifer.

The first species, G. montanus, is known from various humid microhabitats, such as litter, moss and rodent nests (BREGETOVA \& SHCHERBAK 1977), as well as from bark beetle galleries (KIEŁCZEWSKI \& WiŚNIEWSKI 1983), both from the lowlands (e.g. Gwiazdowicz \& Klemt 2004, Gwiazdowicz \& Matysiak 2004; Madej et al. 2011) and mountain areas (Gwiazdowicz \& Skorupski 1996; Skorupski \& GoŁoJuch 1996a; Szymkowiak 1998; Gwiazdowicz \& Biernacik 2000; Gwiazdowicz \& Cichocki 2002; GwiAZDOwicz 2003; SKORUPSKI et al. 2004a, b; KAMCZYC 2006b). The high abundance of this species in the cold and humid rock cracks and crevices is probably connected with its preferences for humid microhabitats.

Veigaia nemorensis is an eurytopic species, which was earlier recorded from litter, decaying wood, soil in meadows, from moss, ant hills, and rodent nests (FARRIER 1957; BREgetova 1961; KARG 1993). Moreover, KiEŁCZEWSKI and WiŚNIEWSKI (1983) found this species in Orthotomicus laricis and Tomicus piniperda galleries. Additionally, it dominated in soil and litter in an earlier study on the Szczeliniec Wielki plateau (KAMCZYC \& GwiAzDOwicz 2009). Previous records indicate that this species is 


\section{A}

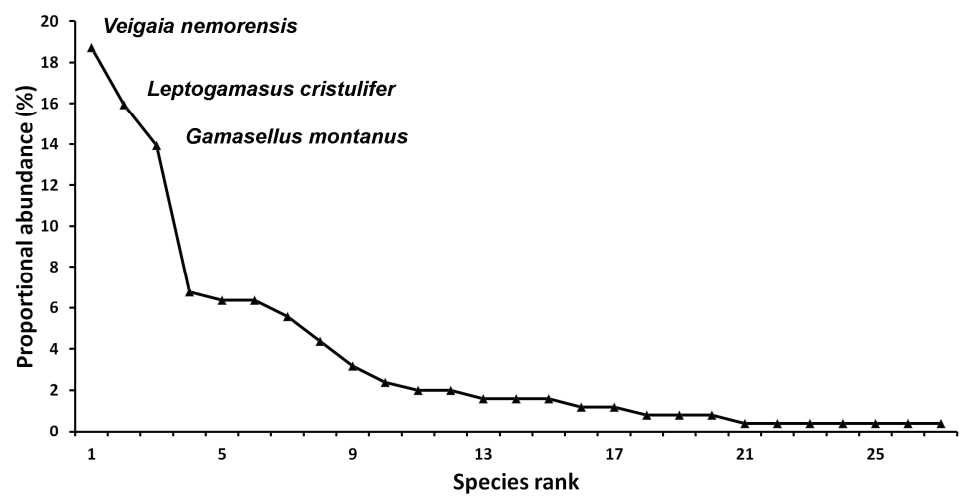

B

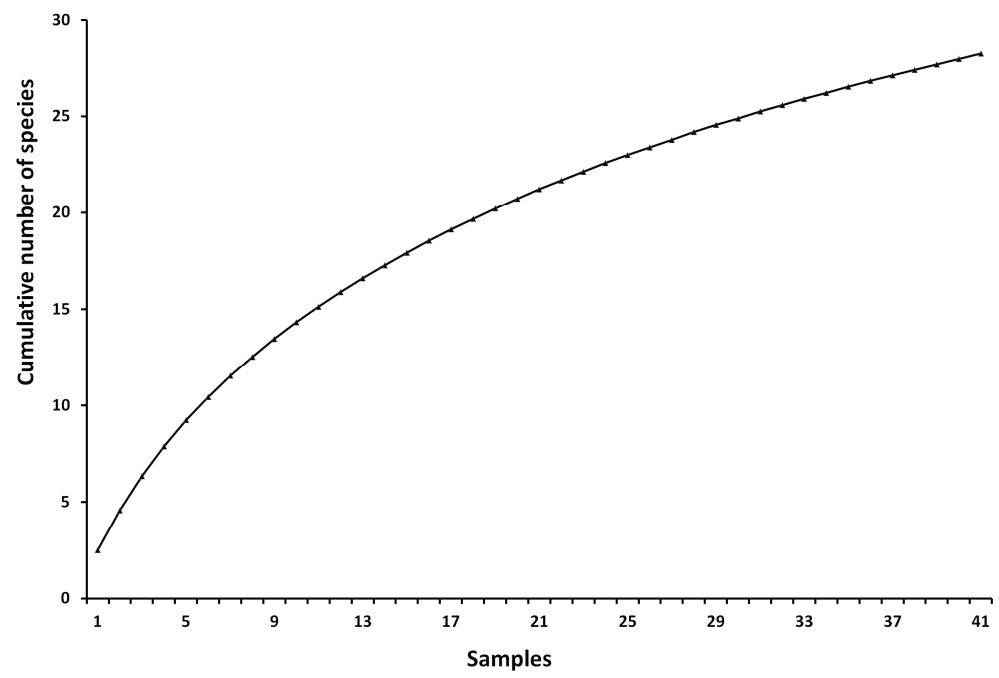

Fig. 1. Proportional abundance (A) and cumulative number of species (B) for the mesostigmatid mite community of soil/litter from the rock cracks and crevices in the Szczeliniec Wielki and Błędne Skały rock labyrinths

also known from many mountain areas (GwiAzdowicz \& SKorupski 1996; SKorupski \& GoŁojuch 1996a; Skorupski \& Gwiazdowicz 1996; Szymkowiak 1998; Gwiazdowicz \& Cichocki 2002; GwiAzdowicz 2003; SKORUPSKi et al. 2004a, b).

Leptogamasus cristulifer is known from litter and moss in deciduous forests (KARG 1993) and was recorded from the Stołowe Mountains NP (SKORUPSKI \& GoŁoJuch 1996a) and also from spruce forest in another part of the Sudetes (SKORUPSKI et al. 2009). Our study is in line with records of KAMCZYC and GwIAZDOwICZ (2009) on the Szczeliniec Wielki plateau, where this species also dominated in the mite community. 
The present study has confirmed the occurrence of rare mites in the analysed microhabitats. This group was represented by Leptogamasus cristulifer, which dominated in the community, as well as Paragamasus insertus and Veigaia mollis, which were less abundant in the rock cracks. The distribution of L. cristulifer and P. insertus in Poland is restricted to the Stołowe Mountains NP (MicherdzińsKi 1969; SKORUPSKI \& GoŁouuch 1996a; Kamczyc \& Gwiazdowicz 2009), while V. mollis, besides the area of the Park (Skorupski \& GoŁouUch 1996a; Kamczyc 2006b; KamcZYC \& GwiazdowICZ 2009), is additionally known from the nature reserve Bielinek in north-western Poland (SKORUPSKI \& ŁABĘDZKi 2004) and from spruce-fir stands in the south-western part of the country (SKORUPSKI et al. 2009).

\section{CONCLUSIONS}

The microhabitat of the rock cracks and crevices creates favourable conditions for eurytopic species that are abundant in humid environments. The Szczeliniec Wielki and Błędne Skały rock labyrinths are also refuges of rare mite species, such as Leptogamasus cristulifer, Paragamasus insertus and Veigaia mollis.

\section{REFERENCES}

BALDY K. 2002. Rola zgrupowań pająków w zooindykacji szczelin piaskowcowych Gór Stołowych [The role of spider communities in bioindication of the rock crack in the Stołowe Mountains]. Par. nar. Rez. przyr. 21: 451-469 (in Polish).

BAldY K., WoźNY M. 1998. Stan zbadania araneofauny na terenie Parku Narodowego Gór Stołowych [State of the aranefauna investigation on the territory of the Stołowe Mts. National Park]. Szczeliniec 2: 89-96 (in Polish).

BŁoszyK J. 1980. Rodzaj Trachytes Michael, 1894 (Acari, Mesostigmata) w Polsce [Mites of the genus Trachytes Michael, 1884 (Acari, Mesostigmata) in Poland]. Pr. Kom. Nauk Biol. PTPN 54: 5-52 (in Polish).

BŁoszyK J., OlsZanowski Z. 1984. Uroseius (Apionoseius) gaieri (Schweitzer, 1961) nowy dla fauny Polski gatunek roztocza (Acari, Uropodina) [Uroseius (Apionoseius) gaieri (Schweitzer, 1961) new species to the fauna (Acari, Uropodina) of Poland. Przegl. Zool. 28: 491-496 (in Polish).

Bregetova N. G. 1961. Klesci semejstwa Veigaiaidae Oudemans, 1939 [Mites from the Veigaiaidae Oudemans, 1939 family]. Fauna SSSR. Parasitol. Sbornik Zool. Inst. AN SSSR 20: 10-107 (in Russian).

Bregetova N. G., Shcherbak G. I. 1977. Semejstvo Rhodacaridae [The Rhodacaridae family]. In: Opredelitiel obitajushchikh v pochvie kleshchey (Ghilarov M.C., BregEtova N.G. Eds.). Nauka (Leningrad): 256-308 (in Russian).

FARrier M. H. 1957. A Revision of Veigaiaidae (Acarina) Tech. Bull. 124:1-103.

Gwiazdowicz D. J. 2003. Mites (Acari, Gamasida) of the tree stands in lower and upper subalpine forests in the Karkonosze National Park. Acta. Sci. Pol. Silv. Colendar. Rat. Ind. Lingar. 2: 5-18.

GwiAzDowicz D. J., BiernaciK R. 2000. Roztocze (Acari, Gamasida) wybranych mikrośrodowisk Karkonoskiego Parku Narodowego [Mites (Acari, Gamasida) of selected microhabitats of Karkonosze National Park]. Opera Corcontica 37: 200-210 (in Polish).

Gwiazdowicz D. J., Cichocki W. 2002. Wstępne badania nad fauną roztoczy (Acari, Gamasida) okolic Zakopanego [Preliminary investigation on Gamasida (Acari) in Zakopane region]. 
In: Przemiany środowiska przyrodniczego Tatr (Borowiec W., Kotarba A., Kownacki A., Krzan Z., Mirek Z., Eds), Tatrzański Park Narodowy, Kraków-Zakopane, pp. 265-269 (in Polish).

Gwiazdowicz D. J., Kamczyc J. 2009. Arctoseius wisniewskii sp. nov. (Acari: Ascidae) from Poland. Ann. Zool. 59: 119-123

Gwiazdowicz D. J., Klemt J. 2004. Mesostigmatic mites (Acari, Gamasida) in selected microhabitats of the Biebrza National Park (NE Poland). Biological Lett. 41: 11-19.

Gwiazdowicz D. J., Matysiak K. 2004. Mites (Acari, Mesostigmata) from selected microhabitats of the „Bory Tucholskie” National Park. Acta Scientiarum Polonorum Silvarum Colendarum Ratio et Industria Lignaria 3: 17-24.

Gwiazdowicz D. J., Skorupski M. 1996. Antennophorina, Microgyniina, Sejina, Gamasina (Acari, Mesostigmata) parków narodowych Polski [Antennophorina, Microgyniina, Gamasina (Acari, Mesostigmata) in Polish national parks]. Par. nar. Rez. przyr. 15: 47-62.

Kaczmarek S., Marquardt T. 2006. Parasitidae (Acari: Gamasida) of the Stołowe Mts. National Park. Biological Lett. 43: 179-185.

KAMCZYC J. 2006a. Microhabitat preferences of Veigaia mollis Karg, 1971 in the mountain reserve „Szczeliniec Wielki”. Biological Lett. 43: 193-195.

KAMCZYC J. 2006b. The population structure of Gamasellus montanus (Willmann, 1936) in three different forest groups in the Szczeliniec Wielki nature reserve. Abh. Ber. Naturkundesmus. 78: $11-17$.

KamcZyc J., Gwiazdowicz D. J. 2009. Soil mites (Acari, Mesostigmata) from Szczeliniec Wielki in the Stołowe Mountains National Park (SW Poland). Biological Lett. 46: 21-27.

KARG W. 1993. Acari (Acarina), Milben Parasitiformes (Anactinochaeta), Cohors Gamasina Leach. Raubmilben. Die Tierwelt Deutschlands, VEB Gustav Fischer Verlag (Jena), Teil 59: 1-523.

KIEŁCZEWSKI B., WiśNIEWSKI J. 1983. Bark beetle acarofauna in different types of forest habitat. Part I and II. Introduction and Mesostigmata. Fol. Forest. Pol. Ser. A. 25: 129-162.

Lindquist E. E., Makarova O. 2011. Two New Circumpolar Mite Species of the Genus Arctoseius Thor (Parasitiformes, Mesostigmata, Ascidae). Entomol. Rev. 91: 1054-1072.

MAdeJ G., BARCZYK G., GAWENDA I. 2011. Importance of microhabitats for preservation of species diversity, on the basis of mesostigmatid mites (Mesostigmata, Arachnida, Acari). Pol. J. Environ. Stud. 20: 961-968.

Micherdziński W. 1969. Die Familie Parasitidae Oudemans, 1901 (Acarina, Mesostigmata). PWN, Kraków.

Plan ochrony exosystemów leśnych. 1998. Opisanie ogólne [General description]. Park Narodowy Gór Stołowych, Kudowa Zdrój.

RYBAK J., BALDY K. 2003. Wybrane aspekty biologii Bathyphantes eumenis (L. Koch, 1879) (Araneae, Linyphidae) [Selected aspects of biology Bathyphantes eumenis (L. Koch , 1879) (Araneae, Linyphidae )]. Szczeliniec 7: 73-85 (in Polish).

Skorupski M., Ciechanowicz A., GoŁojuch P., Święcioch J. 1998. Mites of the family Parasitidae (Acari, Mesostigmata) of the Drawno National Park, Góry Stołowe National Park and Magura National Park. Zesz. Nauk. ATR Bydgoszcz 214, Ochr. Środ. 2: 287-290 (in Polish).

Skorupski M., Butkiewicz G., Wierzbicka A. 2009. The first reaction of soil mite fauna (Acari, Mesostigmata) caused by conversion of Norway spruce stand in the Szklarska Poręba Forest District. J. Forest Sci. 55: 234-243.

Skorupski M., Ciechanowicz A., Kamczyc J. 2004a. Mites (Acari, Mesostigmata) of selected microhabitats of the Magurski National Park. Forestry 7: 59-65.

Skorupski M., GoŁoJuch P. 1996a. Roztocze (Acari, Mesostigmata) wybranych mikrośrodowisk Parku Narodowego Gór Stołowych [Mites (Acari, Mesostigmata) of selected microhabitats in the Stołowe Mts. National Park]. Parki nar. Rez. przyr. 15: 73-79 (in Polish).

Skorupski M., GoŁoJuch P. 1996b. Wstępne wyniki badań nad roztoczami z rzędu Mesostigmata (Acari) Parku Narodowego Gór Stołowych [Preliminary studies on mites Mesostigmata 
(Acari) in the Stołowe Mts. National Park]. Sympozjum naukowe „Środowisko przyrodnicze Parku narodowego Gór Stołowych" 11-13 października, Kudowa Zdrój: 185-188 (in Polish). Skorupski M., Gwiazdowicz D. J. 1996. Roztocze (Acari, Mesostigmata) Pienin [Mites (Acari, Mesostigmata) of the Pieniny]. Fragm. Faun. 39: 223-243.

SkorupsKi M., ŁABĘDZKI A. 2004. Mesostigmata mites in the Bielinek on the Odra reserve. Abh. Ber. Naturkundesmus. 76: 71-80.

Skorupski M., Nowak S., Wierzbicka A. 2004b. Preliminary studies on mites from Mesostigmata order in the Babiogórski National Park. Forestry 7: 67-73.

Smolis A. 2003. Skoczogonki (Collembola) Parku Narodowego Gór Stołowych [Springtails (Collembola) of the Stołowe Mts. National Park]. Szczeliniec 7: 63-71 (in Polish).

Smolis A., Pomorski R. J. 1998. Skoczogonki (Collembola: Insecta) rezerwatu „Szczeliniec Wielki” w Parku Narodowym Gór Stołowych [Springtails (Collembola: Insecta) of the „, Szczeliniec Wielki" reserve in the Stołowe Mts. National Park]. Szczeliniec 2: 97-110 (in Polish).

SzopKa K. 2002. Czynniki przyrodnicze wpływające na zróżnicowanie pokrywy glebowej Gór Stołowych [Natural factors influencing the differentiation in the soil cover of the Stołowe Mountains]. Szczeliniec 6: 11-20 (in Polish).

Szymkowiak P. 1998. Soil Gamasina (Acari, Gamasida) of the fertile carpatian beech forest in the Gorce National Park. Zesz. Nauk. Akademia Techniczno-Rolnicza (Bydgoszcz), 214, Ochrona środowiska 2: 291-298.

Woźny M., CzaJka M. 1985. Bathyphantes eumenis L. Koch, 1879 Aranei, Linyphiidae in Poland, and its synonyms. Pol. Pis. Entomol. 553: 575-582. 